\title{
Increasing intake of dietary soluble nutrients affects digesta passage rate in the stomach of growing pigs
}

\author{
Marijke Schop $^{1,2 *}$, Alfons J. M. Jansman ${ }^{2}$, Sonja de Vries ${ }^{1}$ and Walter J. J. Gerrits ${ }^{1}$ \\ ${ }^{1}$ Animal Nutrition Group, Wageningen University \& Research, PO Box 338, 6700 AH Wageningen, The Netherlands \\ ${ }^{2}$ Wageningen Livestock Research, Wageningen University \& Research, PO Box 338, 6700 AH Wageningen, The Netherlands \\ (Submitted 9 July 2018 - Final revision received 21 November 2018 - Accepted 2 December 2018 - First published online 30 January 2019)
}

\begin{abstract}
The passage rate of solids and liquids through the gastrointestinal tract differs. Increased dietary nutrient solubility causes nutrients to shift from the solid to the liquid digesta fraction and potentially affect digesta passage kinetics. We quantified: (1) the effect of three levels of dietary nutrient solubility (8,19 and $31 \%$ of soluble protein and sucrose in the diet) at high feed intake level (S) and (2) the effect of low $v$. high feed intake level (F), on digesta passage kinetics in forty male growing pigs. The mean retention time (MRT) of solids and liquids in the stomach and small intestine was assessed using $\mathrm{TiO}_{2}$ and Cr-EDTA, respectively. In addition, physicochemical properties of digesta were evaluated. Overall, solids were retained longer than liquids in the stomach $(2 \cdot 0 \mathrm{~h}, P<0.0001)$ and stomach + small intestine $(1.6 \mathrm{~h}, P<0 \cdot 001)$. When $\mathrm{S}$ increased, MRT in stomach decreased by $1.3 \mathrm{~h}$ for solids $(P=0.01)$ and $0.7 \mathrm{~h}$ for liquids $(P=0.002)$ but only at the highest level of $\mathrm{S}$. When $\mathrm{F}$ increased using low-soluble nutrients, MRT in stomach increased by $0.8 \mathrm{~h}$ for solids $(P=0.041)$ and $0.7 \mathrm{~h}$ for liquids $(P=0.0001)$. Dietary treatments did not affect water-binding capacity and viscosity of digesta. In the stomach of growing pigs, dietary nutrient solubility affects digesta MRT in a non-linear manner, while feed intake level increases digesta MRT depending on dietary nutrient solubility. Results can be used to improve predictions on the kinetics of nutrient passage and thereby of nutrient digestion and absorption in the gastrointestinal tract.
\end{abstract}

Key words: Growing pigs: Feed intake: Dietary nutrient solubility: Gastric emptying: Mean retention time

In humans and animals, the appearance kinetics of nutrients in portal blood depends on the kinetics of nutrient passage, hydrolysis and absorption in the gastrointestinal tract (GIT). It has been shown that asynchronous appearance of metabolic complementary nutrients may affect the nutrient's metabolic fate. For example, pigs fed with a free lysine diet $v$. a proteinbound lysine diet ${ }^{(1)}$, or pigs asynchronously fed amino acids and glucose within a day ${ }^{(2)}$ showed an increased loss of amino acids as a result of oxidation. As the small intestine is the main site of nutrient absorption, the kinetics of nutrient passage before this site can influence the kinetics of portal blood appearance. Hence, the kinetics of nutrient passage through the stomach and small intestine is important to consider when one is interested in the metabolic fate of ingested nutrients.

The passage of nutrients through the stomach is a heterogeneous process $^{(3)}$. Due to the morphology and motility of the stomach, solids pass slower than liquids ${ }^{(4,5)}$. After ingestion, solids are first retained in the proximal stomach, whereas liquids rapidly distribute throughout, and empty from the stomach ${ }^{(4)}$. The passage of liquids from the stomach is driven by (fundic) pressure and is related to stomach volume ${ }^{(6,7)}$. Solids, however, first pass from the proximal to distal stomach, where they can be reduced in size before they are emptied into the small intestine ${ }^{(8,9)}$. Moreover, several feedback mechanisms along the GIT are known to control the gastrointestinal motility and inhibit digesta passage from the stomach and/or in the intestines. These feedback mechanisms can be triggered by receptors along the GIT by the presence of protein, carbohydrates and fat degradation products ${ }^{(10,11)}$. Increasing the nutrient load of a meal, for example, resulted in a decreased stomach emptying rate of solids and liquids in both human and pigs ${ }^{(4,12,13)}$. Hence, the rate of passage of solids and liquids through the stomach is a net result of multiple factors that stimulate or inhibit the passage process.

The difference in passage rate of digesta phases (i.e. solids $v$. liquids) and the influence of nutrient load on passage kinetics indicate that dietary nutrient solubility can influence the passage rate of digesta from the stomach. An increase in dietary nutrient solubility causes nutrients to shift from the solid to the liquid digesta fraction. Nutrients in the latter fraction enter the

Abbreviations: BW, body weight; F, feed intake level; GIT, gastrointestinal tract; HF-HS, high feed intake-high nutrient solubility; HF-LS, high feed intake-low nutrient solubility; HF-MS, high feed intake-medium nutrient solubility; LF-LS, low feed intake-low nutrient solubility; MRT, mean retention time; S, nutrient solubility; WBC, water-binding capacity.

* Corresponding author: M. Schop, email Marijke.schop@wur.nl 
small intestine quickly after ingestion, thereby potentially triggering nutrient feedback mechanisms that affect digesta passage kinetics in the proximal GIT. Moreover, relevant variation in nutrient solubility between feed ingredients exists. Protein solubility, for example, varies between $0 \%$ in faba beans and $61 \%$ in maize gluten meal at stomach $\mathrm{pH}^{(14)}$ and close to $90 \%$ in whey protein isolates at $\mathrm{pH} 4 \cdot 6^{(15)}$. While previous studies observed an effect on stomach emptying rate by increasing the nutrient load of the liquid fraction of the diet ${ }^{(4,13)}$, the effect was confounded with the effect of increasing total nutrient intake $^{(12)}$. Although in humans and pigs the passage rate of solids and liquids in the stomach has been studied ${ }^{(4,12,13,16,17)}$, only limited studies have quantified the passage rate of digesta solids and liquids in other segments of the GIT ${ }^{(17)}$. Therefore, this study aimed to evaluate the effects of (1) dietary nutrient solubility (S) and (2) feed intake level (F), on the passage behaviour of solids and liquids in multiple GIT segments of growing pigs. It was hypothesised that an increase in $\mathrm{S}$ or $\mathrm{F}$ would result in an increase in mean retention time (MRT) of solids and liquids in the proximal GIT.

\section{Methods}

The study was approved by the Dutch Animal Ethics Committee (2014.III.06.056) and carried out at the Swine Research Centre of Nutreco N.V. (Sint Anthonis, the Netherlands). This includes daily welfare assessments as required and guided by European legislation (European Commission: Directive 2010/ $63 / \mathrm{EU})$. The study objective considers the pig as the main research subject.

\section{Animals and housing}

A total of forty male growing pigs (Hypor $\times$ Maxter; Hendrix Genetics) with an average initial body weight (BW) of $32 \cdot 0$ (SD 1.4) kg were used. The experiment was performed in two sequential batches of twenty pigs each. Pigs were individually housed in pens $(2.48 \times 0.94 \mathrm{~m})$ equipped with partial slatted floors and half-open walls between pens to allow visual and physical contact of adjacently housed pigs. Temperature was controlled at $23 \pm 1^{\circ} \mathrm{C}$ and the facility was lit from 06.00 to 18.00 hours.

\section{Diets and feeding}

In a randomised complete block design, the pigs were assigned to one of four treatments differing in $\mathrm{S}$ and F. Dietary treatments were a low, medium and high S diet at high F (HF-LS, HF-MS and HF-HS, respectively), and a low $S$ diet at low F (LF-LS). Low and high $\mathrm{F}$ represent feed intake levels of, respectively, 1.9 and $2 \cdot 8 \times$ metabolisable energy requirement for maintenance $\left(\mathrm{ME}_{\mathrm{m}}\right.$ : $\left.419 \mathrm{~kJ} \mathrm{ME} / \mathrm{kg} \mathrm{BW}^{0.75}\right)^{(18)}$. Low, medium and high $\mathrm{S}$ diets consisted of 8,19 and $31 \%$ of soluble protein and glucose equivalents $((\operatorname{starch} / 0 \cdot 9)+$ reducing sugars $)$, respectively. Whereby dietary nutrient solubility was considered as the proportion of nutrients that are soluble when brought in a buffer solution $(\mathrm{pH}$ $3-3 \cdot 5$, stomach $\mathrm{pH}$ in pigs ${ }^{(14,15,19-21)}$.
Table 1. Ingredient composition of the basal low-soluble, and highsoluble diets used to compose the experimental diets

\begin{tabular}{|c|c|c|}
\hline Ingredients (g/kg as-is) & Low soluble & High soluble \\
\hline Wheat & 365.5 & 0.0 \\
\hline Maize & $310 \cdot 0$ & 0.0 \\
\hline Soyabean meal & $140 \cdot 0$ & 0.0 \\
\hline Rapeseed meal & $100 \cdot 0$ & 0.0 \\
\hline Sugar beet pulp & $15 \cdot 0$ & 0.0 \\
\hline Soyabean oil & $18 \cdot 9$ & 41.0 \\
\hline Agglomerated whey* & 0.0 & $238 \cdot 3$ \\
\hline Sucrose & 0.0 & $660 \cdot 0$ \\
\hline Premix $†$ & $5 \cdot 0$ & $5 \cdot 0$ \\
\hline Monocalcium phosphate & $10 \cdot 0$ & $18 \cdot 0$ \\
\hline Limestone & $14 \cdot 0$ & 14.5 \\
\hline Sodium bicarbonate & $5 \cdot 6$ & $13 \cdot 3$ \\
\hline $\mathrm{NaCl}$ & $4 \cdot 0$ & $4 \cdot 0$ \\
\hline L-Lys & $4 \cdot 3$ & 0.0 \\
\hline DL-Met & 0.7 & 0.0 \\
\hline L-Thr & 0.8 & 0.0 \\
\hline L-Trp & 0.3 & 0.0 \\
\hline $\mathrm{TiO}_{2}$ & $4 \cdot 0$ & $4 \cdot 0$ \\
\hline Cr-EDTA & 1.9 & 1.9 \\
\hline
\end{tabular}

* Volactive UltraWhey 90 instant $=$ agglomerated, instantised whey protein isolate $90 \%$ (Volac International Ltd).

† Composition of premix, per kg diet: $2.4 \mathrm{mg}$ vitamin $\mathrm{A}, 40 \mu \mathrm{g}$ vitamin $\mathrm{D}_{3}, 30 \mathrm{mg}$ vitamin $E, 1.5 \mathrm{mg}$ vitamin $K_{3}, 1.0 \mathrm{mg}$ vitamin $B_{1}, 4.0 \mathrm{mg}$ vitamin $B_{2}, 1.5 \mathrm{mg}$ vitamin $B_{6}, 20 \mu \mathrm{g}$ vitamin $B_{12}, 20 \mathrm{mg}$ niacin, $12 \mathrm{mg}$ D-pantothenic acid, $150 \mathrm{mg}$ choline chloride, $0.2 \mathrm{mg}$ folic acid, $100 \mathrm{mg} \mathrm{Fe}$ (as $\mathrm{FeSO}_{4} \cdot \mathrm{H}_{2} \mathrm{O}$ ), $20 \mathrm{mg} \mathrm{Cu}$ (as $\mathrm{CuSO}_{4} .5 \mathrm{H}_{2} \mathrm{O}$ ), $30 \mathrm{mg} \mathrm{Mn}$ (as $\mathrm{MnO}$ ), $70 \mathrm{mg} \mathrm{Zn} \mathrm{(as} \mathrm{ZnSO}_{4} . \mathrm{H}_{2} \mathrm{O}$ ), $0.68 \mathrm{mg}$ iodine (as $\mathrm{KI}$ ) and $0.20 \mathrm{mg} \mathrm{Se}\left(\right.$ as $\mathrm{Na}_{2} \mathrm{SeO}_{3}$ ). Carrier: maize meal.

The experimental diets were composed of two basal diets (Table 1): a basal low-soluble diet and a basal high-soluble diet, these diets were formulated using ingredients covering a low or high range of nutrient solubility, respectively. The basal diets were designed to be equal in crude protein (CP), glucoseequivalents and crude fat content. These basal diets were produced as mash and were mixed in different ratios to obtain the four experimental diets (Table 2). Soyabean meal, maize and wheat were hammer milled to pass a $4-\mathrm{mm}$ sieve, and sugar beet pulp and rapeseed meal to pass a $2 \cdot 75-\mathrm{mm}$ sieve.

All pigs were gradually switched from a commercial diet to the experimental diets in $3 \mathrm{~d}$ before the experiment. The experiment lasted for $18 \mathrm{~d}$ (Fig. 1). Pigs were fed the experimental diets at a feeding level of $2.5 \mathrm{ME}_{\mathrm{m}}$ until day 7 , followed by the feeding level of the respective treatments until the end of the trial. The pigs were fed twice daily at 08.00 and 16.00 hours until day 15 , followed by frequent feeding to induce steady state passage of digesta in the GIT. During the frequent feeding period, the daily feed allowance was divided in six equal portions. On days 16 and 17 , the pigs received portions once every 3 h from 05.30 until 20.30 hours. On day 18, the pigs received portions once every $2 \mathrm{~h}$ from 02.30 hours until $2 \mathrm{~h}$ before euthanasia, with a minimum of three portions fed on this day. Feeding time on this day (day 18) was scheduled according to the scheduled time of euthanasia of each pig, starting at 08.30 hours with the first pig. The diets contained $\mathrm{TiO}_{2}$ as the indigestible insoluble marker ${ }^{(22)}$ from day 8 onwards, and $\mathrm{Cr}$ EDTA as the indigestible soluble marker ${ }^{(23)}$ from day 16 onwards. Diets were fed as mash and mixed with water (1:2.5, $\mathrm{w} / \mathrm{w})$ in the feed trough. In addition, the pigs received 0.5 litre of water/d, 0.25 litre in the morning and 0.25 litre in the 
Table 2. Experimental design: intake of basal diets and resulting intake of nutrients of pigs fed diets with a low nutrient solubility (LS), medium nutrient solubility (MS), or high nutrient solubility (HS), and low feed intake (LF) or high feed intake (HF)*

\begin{tabular}{|c|c|c|c|c|}
\hline & \multicolumn{4}{|c|}{ Experimental treatments } \\
\hline & LF-LS & HF-LS & HF-MS & HF-HS \\
\hline \multicolumn{5}{|c|}{ Diet intake (g DM/kg BW ${ }^{0.75}$ per d) } \\
\hline Basal low-soluble diet & 51 & 76 & 64 & 51 \\
\hline Basal high-soluble diet & 0 & 0 & 10 & 20 \\
\hline \multicolumn{5}{|c|}{ Nutrient intake $\left(\mathrm{g} / \mathrm{kg} \mathrm{BW}^{0.75}\right.$ per $\left.\mathrm{d}\right) \dagger$} \\
\hline DM & 51 & 76 & 74 & 71 \\
\hline Crude protein & $9 \cdot 3$ & 14 & 14 & 13 \\
\hline Soluble protein $\ddagger$ & 1.6 & 2.4 & 3.7 & $5 \cdot 1$ \\
\hline Starch & 23 & 35 & 30 & 24 \\
\hline Reducing sugars & 2.5 & 3.7 & 10 & 17 \\
\hline Glucose equivalents§ & 28 & 43 & 43 & 43 \\
\hline NSP\| & 10 & 16 & 13 & 11 \\
\hline Insoluble NSP|| & 1 & 2 & 2 & 1 \\
\hline MEI $\left(\mathrm{MJ} / \mathrm{kg} \mathrm{BW} \mathrm{W}^{0.75}\right.$ per d) & 0.78 & $1 \cdot 2$ & $1 \cdot 2$ & $1 \cdot 1$ \\
\hline
\end{tabular}

BW, body weight; $\mathrm{ME}$, metabolisable energy.

* Feed intake level at $1.9(\mathrm{LF})$ or $2.8(\mathrm{HF}) \times \mathrm{ME}$ requirement for maintenance $\left(419 \mathrm{~kJ} \mathrm{ME} / \mathrm{kg} \mathrm{BW}{ }^{0.75}\right)^{(18)}$

$\dagger$ Unless stated otherwise.

$\mp$ Protein solubility in phosphate buffer $\mathrm{A}^{(24)}, 0.1 \mathrm{M}$ at $\mathrm{pH} 3.5$ and $39^{\circ} \mathrm{C}$.

$\S$ Glucose equivalents: (starch/0.9) + reducing sugars.

॥ NSP as calculated ${ }^{(25)}$ from diet composition: organic matter - crude protein - crude fat - starch - gluco-oligosaccharides $-0.9 \times$ sugar. Insoluble NSP calculated based on water-insoluble cell wall content from calculated diet composition ${ }^{(26)}$.

II $\mathrm{ME}^{(27)}(\mathrm{MJ})=(20.0 \times$ digestible crude protein $+39.1 \times$ digestible diethyl ether extract $+17.5 \times$ starch $+16.6 \times$ sugars $+17.2 \times$ digestible NSP $) / 1000$.

\begin{tabular}{|c|c|c|c|c|c|c|c|}
\hline Day & $0-7$ & $8-13$ & 14 & 15 & 16 & 17 & 18 \\
\hline $\begin{array}{c}\text { Feed intake } \\
\text { level }\end{array}$ & $2.5 \times \mathrm{ME}_{\mathrm{m}}$ & \multicolumn{5}{c|}{$\begin{array}{c}\text { According to dietary treatment } \\
\left(1.9 \text { or } 2 \cdot 8 \times \mathrm{ME}_{\mathrm{m}}\right)\end{array}$} \\
\hline Meals/d & \multicolumn{5}{|c|}{2} & 6 & $3-6$ \\
\hline $\begin{array}{c}\text { Marker } \\
\text { intake }\end{array}$ & & $\mathrm{TiO}_{2}$ & \multicolumn{5}{|c|}{$\mathrm{TiO}_{2}+\mathrm{Cr}-\mathrm{EDTA}$} \\
\cline { 3 - 6 }
\end{tabular}

Fig. 1. Timeline of the study. $M E_{m}$, metabolisable energy requirement for maintenance.

afternoon. During the frequent feeding period, the pigs did not receive additional water. Twice weekly the pigs were weighed to adjust the amount of feed allowed based on the pigs' BW.

Sample collection and chemical analysis. At day 18, the pigs (45.2 (sD 3.2) kg BW) were euthanised for quantitative digesta collection from various segments of the GIT. Pigs were euthanised sequentially by sedating i.m. with Zoletil ${ }^{\circledR} 100(0.06 \mathrm{ml} / \mathrm{kg}$ BW), followed by injecting Euthasol ${ }^{\circledR}(20 \% ; 24 \mathrm{mg} / \mathrm{kg} \mathrm{BW})$ in the ear vein and exsanguinating via the carotid artery. The sequence of sacrificing pigs was balanced for treatment by block. Each block consisted of four adjacently housed pigs, each pig receiving a different dietary treatment. Immediately after exsanguination, the abdominal cavity was opened and the GIT was divided into segments by placing tie wraps at the beginning and end of the stomach, small intestine, caecum and colon + rectum (further mentioned as colon), and halfway the small intestine and colon. Digesta from the stomach, proximal and distal half of the small intestine, caecum and proximal and distal half of the colon were collected by gentle stripping. After digesta collection, homogenous digesta subsamples were taken and stored at $4^{\circ} \mathrm{C}$, pending measurements of viscosity and water-binding capacity (WBC). The remaining digesta was stored at $-80^{\circ} \mathrm{C}$ pending freeze-drying. After freeze-drying, the samples were centrifugal milled to pass a 1-mm sieve (Retsch ZM 200). The process from euthanasia until sample storage lasted $15 \mathrm{~min} / \mathrm{pig}$.

Diets and digesta were analysed for contents of $\mathrm{DM}^{(28)}, \mathrm{CP}$ $\left(\mathrm{N}^{(29)} \times 6 \cdot 25\right)$, $\operatorname{starch}^{(30)}$, reducing sugars ${ }^{(31)}, \mathrm{Ti}^{(32)}$ and $\mathrm{Cr}$ (measured at $357.9 \mathrm{~nm}^{(33)}$ after sample preparation according to Williams et al. $\left.{ }^{(34)}\right)$. Single analyses were carried out. In addition, $10 \%$ randomly chosen samples were analysed in duplicate to evaluate the precision of the analyses. Precision and thereby results from analyses were considered valid in case over $90 \%$ of observed duplicate differences were below the set maximum allowable differences for the respective nutrients. In absolute terms, maximum differences were set for DM $(2 \mathrm{~g} / \mathrm{kg})$ and for starch $(2 \mathrm{~g} / \mathrm{kg}$, if starch concentration $>100 \mathrm{~g} / \mathrm{kg}$; or $1 \mathrm{~g} / \mathrm{kg}$ if starch concentration $<100 \mathrm{~g} / \mathrm{kg}$ ). In relative terms, maximum differences were set for N (5\%), Ti (5\%) and Cr (10\%). Samples were reanalysed when values were outside the range of the mean value $\pm 2 \times$ sD within treatment and GIT segment.

WBC of digesta was measured using centrifugational force. Fresh digesta samples were centrifuged at $4000 \mathrm{~g}$ for $10 \mathrm{~min}$ at $21^{\circ} \mathrm{C}$ after which the supernatant was decanted. The WBC, in 
$\mathrm{g} / \mathrm{g}$ digesta DM, was calculated as the weighed amount of water retained after decanting. This analysis was performed in duplicate if the quantity of available sample allowed. In total, twenty-five samples were analysed single, 120 in duplicate and for ninety-five samples insufficient materials were available.

Dynamic viscosity of digesta was measured within $96 \mathrm{~h}$ after digesta collection by an MCR502 and MCR301 rheometre (Modular Compact Rheometer; Anton Paar GmbH). Measurements were carried out at $39^{\circ} \mathrm{C}$ with declining shear rates from $50 / \mathrm{s}$ to $1 / \mathrm{s}$ in twenty-five steps. Different geometries were used for digesta from the proximal and distal GIT segments due to the differences in digesta consistencies within these segments. Stomach and small intestinal samples were measured in a $\mathrm{Ti}$ concentric cylinder (i.e. cup) system (CC17SN2540; Anton Paar GmbH). Caecum and colon digesta samples were measured on a Ti parallel profiled plate-plate measuring system (PP25/P2-SN25463, PP25/P2-SN25491; Anton Paar $\mathrm{GmbH}$ ) with a $1.5 \mathrm{~mm}$ gap width.

Calculations and statistics. Calculations and statistics were performed in Statistical Analysis Systems statistical software package version 9.3 (SAS Institute Inc.). The MRT of digesta in each GIT segment was calculated (Eq. (1)) based on the assumption that in a steady state, pool sizes of digestible marker in each segment reflects the MRT of digesta in that segment (discussed by de Vries \& Gerrits $^{(35)}$ ).

$$
\operatorname{MRT}(\mathrm{h})=\frac{\text { Marker pool size in digesta }(\mathrm{g})}{\text { Marker intake }\left(\frac{g}{b}\right)}
$$

where the marker is either $\mathrm{Ti}\left(\right.$ as $\mathrm{TiO}_{2}$ ) or $\mathrm{Cr}$ (as Cr-EDTA). Marker pool sizes in digesta of each GIT segment were calculated by multiplying the digesta marker concentration $(\mathrm{g} / \mathrm{kg}$ DM) by the weight of digesta in the corresponding segment ( $\mathrm{g}$ DM). Marker intake was calculated by multiplying the marker concentration of the diet $(\mathrm{g} / \mathrm{kg} \mathrm{DM})$ by the meal intake at day $18(\mathrm{~kg} \mathrm{DM} / \mathrm{h})$.

The apparent digestibility of starch and protein in the proximal segments (i.e. stomach, proximal and distal half of the small intestine) of the GIT was calculated (Eq. (2)) according to Kotb \& Luckey ${ }^{(36)}$ :

$$
\text { Nutrient digestibility }(\%)=\left(1-\frac{\left(\frac{[\text { Nutrient }]_{\text {digesta }}}{[\text { Marker }]_{\text {digesta }}}\right)}{\left(\frac{[\text { Nutrient }]_{\text {diet }}}{[\text { Marker }]_{\text {diet }}}\right)}\right) \times 100
$$

where $[\text { Nutrient }]_{\text {digesta, }}$ [Nutrient $]_{\text {diet }}$, $[\text { Marker }]_{\text {digesta }},[\text { Marker }]_{\text {diet }}$ are concentrations $(\mathrm{g} / \mathrm{kg} \mathrm{DM})$ of nutrient (CP or starch) and marker ( $\mathrm{Ti}$ or $\mathrm{Cr}$ ) in the digesta or diet samples.

Dynamic digesta viscosity is described to have nonNewtonian shear-tinning flow behaviour ${ }^{(37)}$. Therefore, the non-Newtonian flow behaviour was fitted using a power-law model $^{(38)}$ (Eq. (3)):

$$
\eta=K \dot{\gamma}^{n-1}
$$

where $\eta=$ viscosity $(\mathrm{Pa} \times \mathrm{s}), K=$ consistency constant, $\dot{\gamma}=$ shear rate (per s) and $n=$ power-law index. The power-law model parameters $(K, n)$ were estimated per pig per GIT segment using non-linear least squares regression (PROC NLIN). The viscosity in the Newtonian region at $45 / \mathrm{s}$ was calculated from the powerlaw model and reported.

The effects of the dietary treatments on digesta MRT, nutrient digestibility and viscosity parameters were analysed per GIT segment using a general linear model (PROC GLM). Dietary treatment, batch, treatment $\times$ batch and block were considered as fixed effects, and the pig as experimental unit. Studentised residuals were tested for normality using the Shapiro-Wilk test. Data distribution was visually evaluated to confirm heteroscedasticity. Non-normal distributed variables were transformed (i.e. logarithmic, exponential, reciprocal or quadratic) before the statistical evaluation. Post hoc separation of means was performed after Tukey-Kramer adjustment. Difference between the LF-LS and HF-LS treatment was considered as a pre-planned contrast and evaluated using a contrast statement. Due to unbalanced data and lack of fixed effects, only means and standard deviations of digesta physicochemical properties for WBC and viscosity were reported. Differences in digesta physicochemical properties between GIT segments were analysed using the previously mentioned general linear model including the fixed effect of GIT segment. Results are presented as backtransformed least square means, and pooled standard deviation $\left(\mathrm{SD}_{\text {pooled }}\right)$, unless indicated otherwise. Considering stomach MRT of solids and liquids as the most important parameters of this study, a power larger than 0.95 was reached on the main effect of treatment using retrospective power analysis (PROC GLMPOWER) with a two-sided $\alpha$ level of 0.05 and current study design and results. Differences among means with $P$ values $<0.05$ were considered significant and $P$ values between 0.05 and $0 \cdot 10$ were considered a trend.

\section{Results}

All pigs remained clinically healthy during the study duration and no adverse events were observed in any of the experimental groups. Data of one pig from the HF-LS treatment were excluded from statistical analyses due to feed refusals that exceeded $10 \%$ of the daily feed allowance for seven consecutive days before the pigs' dissection.

\section{Digesta passage}

On average, the MRT of solids was longer than that of liquids in the stomach $(3.2 v .1 .2 \mathrm{~h}, P<0.0001$; Table 3$)$ and in the stomach + small intestine $(5.3 v .3 .7 \mathrm{~h}, P<0.0001)$ but shorter in the distal half of the small intestine $(1.8 v .2 \cdot 3 \mathrm{~h}, P<0.0001)$. The HF-HS pigs had a shorter MRT of solids (2.9 $v .4 \cdot 1 \mathrm{~h}, P=0 \cdot 01)$ and liquids $(0.8 v .1 .5 \mathrm{~h}, P=0.002)$ in the stomach than the HF-MS pigs, but no other differences were observed between treatments varying in the proportion of S (HF-LS $v$. HF-MS $v$. HF-HS). Nutrient solubility did not influence the MRT of solids or liquids in the small intestine. When $\mathrm{F}$ increased with the additional intake of low-soluble nutrients (LF-LS $v$. HF-LS), MRT in the stomach increased for both solids $(2.5 v .3 .3 \mathrm{~h}, P=0.041)$ and liquids $(0.6 v .1 .3 \mathrm{~h}, P=0.0001)$. When $\mathrm{F}$ increased with additional intake of high-soluble nutrients (LF-LS $v$. HF-HS) no effects on MRT in the stomach were observed. In the distal half 
Table 3. Mean retention time $(\mathrm{h})$ of digesta solids $\left(\mathrm{TiO}_{2}\right)$ and liquids $(\mathrm{Cr}-\mathrm{EDTA})$ in consecutive segments of the gastrointestinal tract of pigs subjected to dietary treatments varying in feed intake level and nutrient solubility $\dagger$

(Mean values and standard deviations)

\begin{tabular}{|c|c|c|c|c|c|c|c|c|}
\hline \multirow[b]{2}{*}{ Segment } & \multirow[b]{2}{*}{ Marker } & \multicolumn{4}{|c|}{ Experimental treatmentsł } & \multirow[b]{2}{*}{ SDpooled } & \multicolumn{2}{|c|}{$P \S$} \\
\hline & & LF-LS & HF-LS & HF-MS & HF-HS & & Treatment & LF-LS $v$. HF-LS \\
\hline Stomach & $\begin{array}{l}\mathrm{TiO}_{2} \\
\text { Cr-EDTA } \\
\text { Difference }\end{array}$ & $\begin{array}{l}2 \cdot 5^{\mathrm{a}} \\
0 \cdot 6^{\mathrm{a}} \\
\star \star \star\end{array}$ & $\begin{array}{c}3 \cdot 3^{\mathrm{a}, \mathrm{b}} \\
1 \cdot 3^{\mathrm{b}, \mathrm{c}} \\
\star * *\end{array}$ & $\begin{array}{l}4 \cdot 1^{b} \\
1 \cdot 5^{c} \\
\star \star \star\end{array}$ & $\begin{array}{l}2 \cdot 9^{\mathrm{a}} \\
0 \cdot 8^{\mathrm{a}, \mathrm{b}} \\
\star \star \star\end{array}$ & $\begin{array}{l}0.83 \\
0.43\end{array}$ & $\begin{array}{r}0.001 \\
<0.001\end{array}$ & $\begin{array}{r}0.041 \\
<0.001\end{array}$ \\
\hline Proximal SI & $\begin{array}{l}\mathrm{TiO}_{2} \\
\mathrm{Cr} \text {-EDTA } \\
\text { Difference }\end{array}$ & $\begin{array}{l}0.4 \\
0.3 \\
\star *\end{array}$ & $\begin{array}{l}0.3 \\
0.3\end{array}$ & $\begin{array}{l}0.3 \\
0.2\end{array}$ & $\begin{array}{l}0.4 \\
0.3\end{array}$ & $\begin{array}{l}0.16 \\
0.14\end{array}$ & $\begin{array}{l}0.382 \\
0.355\end{array}$ & $\begin{array}{l}0.719 \\
0.355\end{array}$ \\
\hline Distal SI & $\begin{array}{l}\mathrm{TiO}_{2} \\
\text { Cr-EDTA } \\
\text { Difference }\end{array}$ & $\begin{array}{l}2 \cdot 1^{b} \\
2 \cdot 5 \\
\star \star \star\end{array}$ & $\begin{array}{l}1 \cdot 7^{\mathrm{a}} \\
2 \cdot 3 \\
\star \star \star \star\end{array}$ & $\begin{array}{l}1 \cdot 6^{\mathrm{a}} \\
2 \cdot 0 \\
\star \star \star\end{array}$ & $\begin{array}{l}1 \cdot 7^{a} \\
2 \cdot 2 \\
\star \star \star \star\end{array}$ & $\begin{array}{l}0.32 \\
0.43\end{array}$ & $\begin{array}{l}0.003 \\
0.155 \|\end{array}$ & $\begin{array}{l}0.006 \\
0.371\end{array}$ \\
\hline Stomach+SI & $\begin{array}{l}\mathrm{TiO}_{2} \\
\text { Cr-EDTA } \\
\text { Difference }\end{array}$ & $\begin{array}{l}5 \cdot 0 \\
3 \cdot 4 \\
\star \star \star\end{array}$ & $\begin{array}{l}5 \cdot 1 \\
4 \cdot 0 \\
* \star\end{array}$ & $\begin{array}{r}6.0 \\
3.9 \\
\star \star\end{array}$ & $\begin{array}{c}5 \cdot 0 \\
3 \cdot 4 \\
\star \star \star \star\end{array}$ & $\begin{array}{l}0.92 \\
0.70\end{array}$ & $\begin{array}{l}0.071 \\
0.105\end{array}$ & $\begin{array}{l}0.748 \\
0.068\end{array}$ \\
\hline
\end{tabular}

LF-LS, low feed intake-low nutrient solubility; HF-LS, high feed intake-low nutrient solubility; HF-MS, high feed intake-medium nutrient solubility; HF-HS, high feed intake-high nutrient solubility; SI, small intestine; ME, metabolisable energy; MRT, mean retention time.

a,b,c Mean values within a row with unlike superscript letters were significantly different $(P<0.05)$.

Significant difference between MRT of the solid and liquid phases of digesta per treatment within segment: ${ }^{\star \star} P<0.001,{ }^{* * \star} P<0.0001$.

† Feed intake level at 1.9 (LF) or 2.8 (HF) $\times$ ME requirement for maintenance $\left(419 \mathrm{~kJ} \mathrm{ME} / \mathrm{kg} \mathrm{BW}^{0.75}\right)^{(18)}$. Dietary nutrient solubility levels were $8 \%$ (LF-LS and HF-LS), $19 \%$ (HF-MS) and $31 \%$ (HF-HS) regarding the amount of soluble protein and sucrose in the diet.

$\ddagger$ Number of pigs per treatment: HF-LS=9; LF-LS, HF-MS and HF-HS=10.

$\S$ Model established $P$ values for fixed effects of treatment (overall dietary treatments), and the contrast between low or high feed intake level (LF-LS $v$. HF-LS).

॥ Significant treatment $\times$ batch effect $(P=0.025)$ for liquid phase MRT.

of the small intestine, the MRT of solids decreased with additional intake of low-soluble nutrients (LF-LS $v$. HF-LS: $2 \cdot 1 v$. $1.7 \mathrm{~h}, P=0.006)$ as well as high-soluble nutrients (LF-LS $v$. HFHS: $2 \cdot 1 v \cdot 1 \cdot 7 \mathrm{~h}, P=0 \cdot 03)$.

Nutrient digestibility. Digestibility of starch was calculated using $\mathrm{TiO}_{2}$ as marker, and apparent protein digestibility using both $\mathrm{TiO}_{2}$ and Cr-EDTA as markers. Calculated digestibility values of starch $\left(\mathrm{TiO}_{2}\right)$ and protein (Cr-EDTA) in the stomach were negative and therefore not presented. Dietary treatment did not affect starch digestibility (Table 4). When $\mathrm{F}$ increased with additional intake of low-soluble nutrients, only the apparent protein digestibility (based on Cr-EDTA) increased in the proximal half of the small intestine (LF-LS $v$. HF-LS: $-6 v$. $25 \%, P=0.013)$

Physicochemical properties. Dietary treatments did not affect the physicochemical properties of digesta in any GIT segment $(P>0 \cdot 12)$ as within-treatment variation was greater than between treatment variation (online Supplementary material). Therefore, results are presented as descriptive statistics (Table 5). Results on the WBC of digesta in the proximal half of the small intestine are not presented due to an insufficient number of samples. The average WBC of digesta was lowest in the stomach $(1.9 \mathrm{~g} / \mathrm{g}$ digesta $\mathrm{DM})$ and highest in the caecum $(5.7 \mathrm{~g} / \mathrm{g}$ digesta DM) compared to the WBC of digesta in any other GIT segment $(P<0 \cdot 005)$. Dynamic viscosity properties of digesta, partly represented by apparent viscosity at $45 / \mathrm{s}$ and $K$, were on average higher in the distal half of the small intestine than in other GIT segments (visco 45: 8.4 $>2 \cdot 2-3 \cdot 3 \mathrm{~Pa} \times \mathrm{s}$, $P<0 \cdot 0001 ; K: 177>35-54$ Pa $\times$ s,$P<0 \cdot 0001)$.

\section{Discussion}

This study aimed to evaluate the effects of (1) nutrient solubility and (2) feed intake level on the MRT of the solid and liquid digesta fraction in several GIT segments in growing pigs. The experimental design allowed to study the effects of (1) $S$ as the proportion of soluble nutrients within the diet (HF-LS $v$. HF-MS $v$. HF-HS), (2) F (LF-LS $v$. HF-LS) on the MRT of digesta solids and liquids in the stomach and small intestine and (3) the dependency of F on S (i.e. LF-LS $v$. HF-LS or HF-HS). Based on ingredient selection, nutrient solubility of the low-soluble diet is considered representative for commercially fed dry diets to growing pigs. Dietary nutrient solubility was increased by exchanging low-soluble ingredients for high-soluble ingredients, thereby covering the range of variation in solubility between ingredients regarding protein (from $4 \%$ in wheat to $>80 \%$ in whey protein isolate) ${ }^{(15,19)}$ and starch (i.e. glucoseequivalents; from $4 \%$ in wheat to $100 \%$ in sucrose $)^{(19)}$. Concerning the treatments differing in $\mathrm{S}$, the proportion of soluble nutrients in the diet increased from the HF-LS to the HF-HS treatment with a factor 2.3 for protein and 4.6 for glucose equivalents. Hereby, $45 \mathrm{~kJ}$ gross energy/kg metabolic BW per meal was shifted from insoluble to soluble nutrients, exceeding the nutrient load (approximately $33 \mathrm{~kJ}$ gross energy $/ \mathrm{kg}$ metabolic BW per meal) that induced an effect on gastric emptying rate in previous studies in humans ${ }^{(4,13)}$.

Although it was expected that an increased intake of soluble nutrients could reduce gastric emptying through stimulation of nutrient feedback mechanisms in the small intestine ${ }^{(4,13)}$, the results in the present study do not support this hypothesis. Instead, increasing $S$, via the relative higher intake of soluble nutrients, resulted in a decreased MRT of digesta in the stomach. The latter indicates faster emptying of the stomach. This result, however, was only observed when $\mathrm{S}$ increased to 
the highest level applied (HF-MS to HF-HS), thereby indicating a non-linear effect of $S$ on the MRT of digesta in the stomach. Previous studies showed an increase in MRT of digesta in the stomach with additional intake of soluble nutrients, the effect however being confounded with the effect of total nutrient and energy intake (1230 v. $1967 \mathrm{~kJ}$ gross energy/meal). Whereas it has also been shown that increasing feed intake level causes increased stomach MRT in both pigs and humans ${ }^{(12,39)}$. By shifting nutrients from the solid to the liquid fraction of digesta in our study, we expected stimulation of nutrient feedback mechanisms in the small intestine by the rapid postprandial appearance of soluble nutrients in that segment. It seems that the intake of the high-soluble nutrients in this study to increase $\mathrm{S}$ and $\mathrm{F}$ were not able to trigger the feedback mechanisms. As the feedback mechanisms regulating digesta passage are complex in nature and their stimulation depends on many factors such as the type of stimuli, GIT location and duration of stimulation $^{(9-11,40)}$. Potentially the stimulus duration was too short, as high-soluble nutrients are generally absorbed rapidly after entering the small intestine ${ }^{(41,42)}$. Unfortunately, the study design does not allow to speculate the dietary or animal factors that particularly caused the non-linear effect of $S$ the passage kinetics of digesta.

The effect of $\mathrm{F}$ was dependent on $\mathrm{S}$, as additional intake of high-soluble nutrients did not affect the digesta passage from the stomach, while additional intake of low-soluble nutrients caused the MRT of digesta in the stomach to increase. This is in agreement with the previous findings, where an increase in feed intake level caused stomach MRT to increase ${ }^{(12,39)}$. It seems that the low-soluble nutrients were able to stimulate nutrient feedback mechanisms in the small intestine, in contrast to the high-soluble nutrients. As with solids, the passage of additional low-soluble nutrients depends on the gradual trituration process in the stomach ${ }^{(41)}$ which might also have caused the observed increase in MRT.

In the small intestine, no effects of S on the MRT of solids and liquids were observed. The dietary treatments with low, medium or high $S$ were designed to provide equal amounts of digestible nutrients. Exchange of ingredients from the low $\mathrm{S}$ to the high $\mathrm{S}$ diet resulted in a slightly lower intake of NSP in pigs fed the HF-LS $v$. HF-MS and HF-HS. Differences in intake of NSP was not corrected by adding fibres, as (purified) fibres can affect physicochemical properties of digesta and subsequently affect gastric emptying rate ${ }^{(43)}$. As current dietary treatments were not designed to evoke effects on physicochemical properties of digesta, these properties were analysed for confirmation. The results confirmed that dietary treatment caused no differences between the physicochemical properties of digesta.

Regarding the digestibility of protein and starch in the small intestine, no treatment effects were observed, except in the proximal half of the small intestine. In the proximal half of the small intestine, using Cr-EDTA as marker, the apparent protein digestibility was lower for pigs fed low F compared to pigs fed high $\mathrm{F}$ (LF-LS $v$. HF-LS). Negative digestibility values observed in particular GIT segments are likely related to endogenous protein secretions and/or discrepancies between the passage rates of nutrients and trace markers. The discrepancy in 
Table 5. Hydration and dynamic viscosity properties of digesta per gastrointestinal tract segment (Mean values and standard deviations)

\begin{tabular}{|c|c|c|c|c|}
\hline Physicochemical property & Segment & Number of pigs & Mean & SD \\
\hline \multicolumn{5}{|l|}{ Hydration } \\
\hline \multirow{6}{*}{ Water-binding capacity (g water/g DM) } & Stomach & 27 & 1.9 & 0.76 \\
\hline & Proximal SI & $N^{*}$ & $N^{*}$ & $\mathrm{ND}^{*}$ \\
\hline & Distal SI & 36 & $3 \cdot 8$ & 1.30 \\
\hline & Caecum & 7 & $5 \cdot 7$ & 0.86 \\
\hline & Proximal C & 39 & 3.8 & $1 \cdot 10$ \\
\hline & Distal C & 30 & 3.9 & $1 \cdot 10$ \\
\hline \multicolumn{5}{|l|}{ Viscosity† } \\
\hline \multirow[t]{6}{*}{ Apparent viscosity at 45/s shear rate (visco45) (Paxs) } & Stomach & 39 & $3 \cdot 1$ & 1.92 \\
\hline & Proximal SI & 36 & $2 \cdot 7$ & 4.05 \\
\hline & Distal SI & 39 & $8 \cdot 4$ & $6 \cdot 79$ \\
\hline & Caecum & 36 & $2 \cdot 2$ & 2.63 \\
\hline & Proximal C & 39 & 2.5 & $1 \cdot 22$ \\
\hline & Distal C & 39 & $3 \cdot 3$ & 1.98 \\
\hline \multirow[t]{6}{*}{ Power-law index $(n)$} & Stomach & 39 & 0.38 & 0.417 \\
\hline & Proximal SI & 36 & 0.32 & 0.167 \\
\hline & Distal SI & 39 & 0.20 & 0.066 \\
\hline & Caecum & 36 & 0.21 & 0.136 \\
\hline & Proximal C & 39 & 0.23 & 0.080 \\
\hline & Distal C & 39 & 0.29 & 0.111 \\
\hline \multirow[t]{6}{*}{ Consistency constant (K) (Paxs) } & Stomach & 39 & 45 & 33.5 \\
\hline & Proximal SI & 36 & 54 & 83.9 \\
\hline & Distal SI & 39 & 177 & $140 \cdot 9$ \\
\hline & Caecum & 36 & 35 & $27 \cdot 0$ \\
\hline & Proximal C & 39 & 49 & $34 \cdot 2$ \\
\hline & Distal C & 39 & 52 & $33 \cdot 0$ \\
\hline
\end{tabular}

SI, small intestine; ND, not determined; C, colon.

* Due to insufficient observations (one observation).

$\dagger$ Viscosity parameters derived by using a power-law function ${ }^{(33)}: \eta=K \dot{\gamma}^{n-1}$, where $\eta=$ viscosity in Paxs, $K=$ consistency constant, $\dot{\gamma}=$ shear rate $(/ \mathrm{s})$ and $n=$ power-law index.

apparent protein digestibility values when using either $\mathrm{TiO}_{2}$ or Cr-EDTA as marker likely results from shifts of nutrients, and possibly of markers, between the solid and liquid digesta fractions during transit through the $\mathrm{GIT}^{(34)}$. However, as digesta transits along the GIT nutrients are hydrolysed and absorbed, and digesta becomes more homogenous. Therefore, differences between passage rates of solids and liquids become smaller, and artefacts in calculations of nutrient digestibility reduce.

In conclusion, the MRT of solids was greater than that of liquids in the stomach and stomach + small intestine. Dietary nutrient solubility affected the stomach MRT of solids and liquids in a non-linear manner. When $\mathrm{S}$ increased, the stomach MRT of solids and liquids decreased, but only at the highest level of S. Feed intake level increased stomach MRT of solids and liquids, only when $\mathrm{F}$ increased with additional low-soluble nutrients. Furthermore, F decreased the MRT of solids and, to some extent, of liquids in the distal small intestine. Hence, dietary nutrient solubility and feed intake level affect the passage rate of digesta. These study results can be used to better predict the metabolic fate of nutrients, taking into account the kinetics of nutrient passage and thereby the kinetics of nutrient absorption.

\section{Acknowledgements}

The authors would like to thank Jennifer Ellis, Piet van Wikselaar, Gera Uittenbogaard, Ruud Dekker, Jos Sewalt
(Wageningen University and Research, Wageningen, the Netherlands), Carlijn de Bruijn, Martien Nooijen, Jos Weerts and animal caretakers at the Swine Research Centre (Boxmeer, the Netherlands) for their advice and/or skilled assistance during the set-up and practical work of this study.

This research was carried out and funded within the framework of the public-private partnership 'Feed4Foodure' ('Vereniging Diervoederonderzoek Nederland' (VDN) and the Dutch Ministry of Economic Affairs and Climate Policy; BO-31.03-005001).

M. S., A. J. M. J. and W. J. J. G. designed research; M. S. conducted research and handled data; M. S., A. J. M. J., S. d. V. and W. J. J. G. interpreted data and wrote paper. All authors read and approved the final manuscript.

The authors declare that there are no conflicts of interest.

\section{Supplementary material}

For supplementary material/s referred to in this article, please visit https://doi.org/10.1017/S0007114518003756

\section{References}

1. Batterham ES \& Bayley HS (1989) Effect of frequency of feeding of diets containing free or protein-bound lysine on the oxidation of $\left[{ }^{14} \mathrm{C}\right] l y s i n e$ or $\left[{ }^{14} \mathrm{C}\right]$ phenylalanine by growing pigs. Br J Nutr 62, 647-655. 
2. van den Borne JJGC, Schrama JW, Heetkamp MJW, et al. (2007) Synchronising the availability of amino acids and glucose increases protein retention in pigs. Animal 1, 666-674.

3. Minami H \& McCallum RW (1984) The physiology and pathophysiology of gastric emptying in humans. Gastroenterology 86, 1592-1610.

4. Collins PJ, Houghton LA, Read NW, et al. (1991) Role of the proximal and distal stomach in mixed solid and liquid meal emptying. Gut 32, 615-619.

5. Holt S, Reid J, Taylor TV, et al. (1982) Gastric emptying of solids in man. Gut 23, 292-296.

6. Kwiatek MA, Menne D, Steingoetter A, et al. (2009) Effect of meal volume and calorie load on postprandial gastric function and emptying: studies under physiological conditions by combined fiber-optic pressure measurement and MRI. Am J Physiol Gastrointest Liver Physiol 297, G894-G901.

7. Strunz UT \& Grossman MI (1978) Effect of intragastric pressure on gastric emptying and secretion. Am J Physiol Endocrinol Metab 235, E552-E555.

8. Meyer JH, Ohashi H, Jehn D, et al. (1981) Size of liver particles emptied from the human stomach. Gastroenterology $\mathbf{8 0}$, 1489-1496.

9. Marciani L, Gowland PA, Fillery-Travis A, et al. (2001) Assessment of antral grinding of a model solid meal with echo-planar imaging. Am J Physiol Gastrointest Liver Physiol 280, G844-G849.

10. Gregory PC, McFadyen M \& Rayner DV (1989) Control of gastric emptying in the pig: influence of duodenal infusions of glucose and emulsified fat. Exp Physiol 74, 109-119.

11. van Citters GW \& Lin HC (2006) Ileal brake: neuropeptidergic control of intestinal transit. Curr Gastroenterol Rep 8, 367-373.

12. Gregory PC, McFadyen M \& Rayner DV (1990) Pattern of gastric emptying in the pig: relation to feeding. Br J Nutr $\mathbf{6 4}$, $45-58$.

13. Houghton LA, Read NW, Heddle R, et al. (1988) Relationship of the motor activity of the antrum, pylorus, and duodenum to gastric emptying of a solid-liquid mixed meal. Gastroenterology 94, 1285-1291.

14. Cone JW (1993) The influence of $\mathrm{pH}$ on in vitro protein solubility and enzymatic hydrolysis of protein in feedstuffs. J Anim Feed Sci 2, 67-72.

15. de Wit JN (1998) Nutritional and functional characteristics of whey proteins in food products. J Dairy Sci 81, 597-608.

16. Camilleri M, Malagelada JR, Brown ML, et al. (1985) Relation between antral motility and gastric emptying of solids and liquids in humans. Am J Physiol Gastrointest Liver Physiol 249, G580-G585.

17. Wilfart A, Montagne L, Simmins H, et al. (2007) Digesta transit in different segments of the gastrointestinal tract of pigs as affected by insoluble fibre supplied by wheat bran. Br J Nutr 98, 54-62.

18. CVB (2005) Protocol for a Faecal Digestibility Trial with Intact Growing Pigs. Lelystad, The Netherlands: Centraal Veevoeder Bureau.

19. Wilfart A, Jaguelin-Peyraud Y, Simmins H, et al. (2008) Kinetics of enzymatic digestion of feeds as estimated by a stepwise in vitro method. Anim Feed Sci Technol 141, 171-183.

20. Chen H (2017) Protein digestion kinetics in pigs and poultry. PhD Dissertation, Wageningen University, The Netherlands.

21. Anguita M, Gasa J, Martín-Orúe SM, et al. (2006) Study of the effect of technological processes on starch hydrolysis, nonstarch polysaccharides solubilization and physicochemical properties of different ingredients using a two-step in vitro system. Anim Feed Sci Technol 129, 99-115.
22. Jagger S, Wiseman J, Cole DJA, et al. (1992) Evaluation of inert markers for the determination of ileal and faecal apparent digestibility values in the pig. Br J Nutr 68 , 729-739.

23. Udén P, Colucci PE \& Van Soest PJ (1980) Investigation of chromium, cerium and cobalt as markers in digesta. Rate of passage studies. J Sci Food Agric 31, 625-632.

24. Boisen S \& Fernández JA (1997) Prediction of the total tract digestibility of energy in feedstuffs and pig diets by in vitro analyses. Anim Feed Sci Technol 68 , 277-286.

25. CVB (2016) Veevoedertabel 2016: chemische samenstellingen en nutritionele waarden van voedermiddelen (Feed Table 2016: Chemical Composition and Nutritional Value of Feed Ingredients). Rijswijk, The Netherlands: Centraal Veevoeder Bureau.

26. INRA-CIRAD-AFZ Feed Tables (2018) Water insoluble cell walls. https://feedtables.com/content/water-insoluble-cellwalls (accessed September 2018).

27. Noblet J, Fortune H, Shi XS, et al. (1994) Prediction of net energy value of feeds for growing pigs. J Anim Sci 72, 344-354.

28. ISO 6496:1999 (1999) Animal Feeding Stuffs - Determination of Moisture and Other Volatile Matter Content, vol. ISO 6496:1999. Geneva: International Organization for Standardization.

29. ISO 5983:2005 (2005) Animal Feeding Stuffs - Determination of Nitrogen Content and Calculation of Crude Protein Content - Part 1 Kjeldahl Method, vol. ISO 5983:2005. Geneva: International Organization for Standardization.

30. ISO 15914:2004 (2004) Animal Feeding Stuffs Enzymatic Determination of Total Starch Content, vol. ISO 15914:2004. Geneva: International Organization for Standardization.

31. van Vuuren AM, van der Koelen CJ, Valk H, et al. (1993) Effects of partial replacement of ryegrass by low protein feeds on rumen fermentation and nitrogen loss by dairy cows. J Dairy Sci 76, 2982-2993.

32. Myers WD, Ludden PA, Nayigihugu V, et al. (2004) A procedure for the preparation and quantitative analysis of samples for titanium dioxide. J Anim Sci 82, 179-183.

33. van Bussel W, Kerkhof F, van Kessel T, et al. (2010) Accurate determination of titanium as titanium dioxide for limited sample size digestibility studies of feed and food matrices by inductively coupled plasma optical emission spectrometry with real-time simultaneous internal standardization. Atom Spectrosc 31, 81-88.

34. Williams CH, David DJ \& Iismaa O (1962) The determination of chromic oxide in faeces samples by atomic absorption spectrophotometry. J Agric Sci 59, 381-385.

35. de Vries S \& Gerrits WJJ (2018) The use of tracers or markers in digestion studies. In Feed Evaluation Science, pp. 274295 [PJH Moughan and WH Hendriks, editors]. Wageningen: Wageningen Academic Publishers.

36. Kotb AR \& Luckey TD (1972) Markers in nutrition. Nutr Abstr Rev 42, 813-845.

37. Dikeman CL, Barry KA, Murphy MR, et al. (2007) Diet and measurement techniques affect small intestinal digesta viscosity among dogs. Nutr Res 27, 56-65.

38. Shelat KJ, Nicholson T, Flanagan BM, et al. (2015) Rheology and microstructure characterisation of small intestinal digesta from pigs fed a red meat-containing Western-style diet. Food Hydrocolloids 44, 300-308.

39. Moore JG, Christian PE \& Coleman RE (1981) Gastric emptying of varying meal weight and composition in man. Dig Dis Sci 26, 16-22. 
40. Lin HC, Doty JE, Reedy TJ, et al. (1989) Inhibition of gastric emptying by glucose depends on length of intestine exposed to nutrient. Am J Physiol Gastrointest Liver Physiol 256, G404-G411.

41. Kong F \& Singh RP (2008) Disintegration of solid foods in human stomach. $J$ Food Sci $\mathbf{7 3}$ R67-R80.
42. Rerat AA (1985) Intestinal absorption of end products from digestion of carbohydrates and proteins in the pig. Arch Tierernaehr 35, 461-480.

43. Guerin S, Ramonet Y, Lecloarec J, et al. (2001) Changes in intragastric meal distribution are better predictors of gastric emptying rate in conscious pigs than are meal viscosity or dietary fibre concentration. Br J Nutr 85, 343-350. 